\title{
A VÁROSI TERÜLETHASZNÁLAT MONOCENTRIKUS MODELLJÉRŐL
}

\author{
(On the Monocentric Model of Urban Land Use)
}

\author{
LENGYEL IMRE - MOZSÁR FERENC
}

\begin{abstract}
Kulcsszavak:
monocentrikus városmodell, területhasználat intenzitása, ajánlati bérleti díj függvény, policentrikus városmodell

A városokban a területhasználatot, ehhez kapcsolódva a településszerkezetet, valamint az ingatlanok kínálatának és keresletének jellemzöit többféle módon és különbözö modellekkel lehet vizsgálni. A városgazdaságtanban közismert a monocentrikus városmodell, amelyet Alonso dolgozott ki 1964-ben, továbbfejlesztve Thünen mezögazdasági földhasználatra vonatkozó elméletét. Alonso a bérleti dij függvény bevezetésével a neoklasszikus közgazdaságtan alapgondolatait, fogalmait és módszereit alkalmazta a városszerkezet vizsgálatára, arra törekedett, hogy a városi földterület kinálata és kereslete közötti térbeli egyensúly jellemzöit kimutassa.

Tanulmányunkban a legfontosabb fogalmak bevezetése után ismertetjük a monocentrikus városmodell alapgondolatait. Részletesen levezetjük a területhasználat intenzitását megadó kifejezéseket, amelyekkel a vállalatok bérleti dijjait leíró függvények jellemezhetök, valamint elemezzük a háztartásoknak a lakásválasztáshoz kapcsolódó döntéseit. A kétféle mikroszervezet, a vállalatok és háztartások ajánlati bérleti díj függvényei alapján bemutatjuk a monocentrikus modellt és napjainkban érvényesnek tekinthetó policentrikus kiterjesztését. A dolgozatban a nemzetközi szakirodalom azon legújabb alapvetö elméleti eredményeit tekintjük át és értelmezzük, amelyek széles körben elfogadottak.
\end{abstract}

\section{Bevezetés}

A városokban a területhasználatot, ehhez kapcsolódva a településszerkezetet, valamint az ingatlanok kínálatának és keresletének jellemzöit többféle módon és különböző modellekkel lehet vizsgálni. A városgazdaságtanban közismert a monocentrikus városmodell, amelyet Alonso dolgozott ki 1964-ben, továbbfejlesztve Thünen mezőgazdasági földhasználatra vonatkozó elméletét. Alonso a neoklaszszikus közgazdaságtan alapgondolatait, fogalmait és módszereit (költségvetési egyenlet, hasznosságfüggvény, közömbösségi görbék stb.) alkalmazta a városszerkezet vizsgálatára, arra törekedett, hogy a városi földterület kínálata és kereslete közötti térbeli egyensúly jellemzöit kimutassa (Alonso 1964; Fujita-Thisse 2002; Harvey 1996; McCann 2001). Az elmúlt évtizedekben a monocentrikus modellt többen kiterjesztették, föleg Fujita, Henderson, Mills és Muth munkássága emelhetö ki (Anas-Arnott-Small 1998; Fujita 1989; Henderson 1996a; Mills-Hamilton 1994; Muth 1996).

A városok szerkezetének jellemzőivel sokan foglalkoztak a településtudomány, településföldrajz és városszociológia müvelöi közül, ezeken a tudományterületeken széles körben elismert alapvető eredmények születtek, de a közgazdászok korábban nem találták meg azokat a fogalmakat és eszközöket, amelyek segítségével a városi 
területhasználat elméleti kérdései a közgazdaságtan szokásos eszközeivel elemezhetők lettek volna. Alonso egy pontszerü piacból kiindulva az ajánlati bérleti díj függvény bevezetésével a háztartások költségvetési egyenlete alapján megadta, hogyan formalizálhatók a háztartások döntései. A monocentrikus modellt a városvizsgálatok ,alapmodelljének” is nevezik, mivel egyszerüsége ellenére a városgazdaságtan minden fontos kérdése tárgyalható a segítségével, illetve a bonyolultabb modellek többsége is visszavezethető rá (Anas-Arnott-Small 1998). Az elmúlt években Thünen „újrafelfedezésével” párhuzamosan a monocentrikus modell is reneszánszát éli, úgy tünik, hogy a térgazdaságtan, az „új gazdasági földrajz”, a megújuló regionális és városgazdaságtan egyik kiindulópontjává vált (Arnott 1996; Fujita-Krugman-Venables 1999; Fujita-Thisse 2002; McCann 2001; Varga 2002).

Tanulmányunkban a legfontosabb fogalmak bevezetése után ismertetjük a monocentrikus városmodell alapgondolatait. Részletesen levezetjük a területhasználat intenzitását megadó kifejezéseket, amelyekkel a vállalatok bérleti díjait leíró függvények jellemezhetők. Szintén elemezzük a háztartásoknak a lakásválasztáshoz kapcsolódó döntéseit. A kétféle mikroszervezet, a vállalatok és háztartások ajánlati bérleti díj függvényei alapján bemutatjuk a monocentrikus modellt és napjainkban érvényesnek tekinthető policentrikus kiterjesztését. A dolgozatban a nemzetközi szakirodalom azon alapvető elméleti eredményeit tekintjük át és értelmezzük, amelyek külföldön a szakirányú egyetemi, illetve doktori kurzusok anyagának sztenderd részét alkotják. Remélhetőleg ezek az új eredmények nemsokára megjelennek a hazai felsőfokú képzések tananyagában is, főleg azért, mivel a közgazdasági felsőoktatás bevezető tárgyainak (mikro- és makroökonómia, analízis) ismeretanyagára épülnek.

\section{A monocentrikus városmodell}

A települések területhasználatára, a városok szerkezetének elemzésére többféle megközelítés létezik, a témakörrel foglalkozók a modellek sokaságát dolgozták ki (Anas 1996; Anas-Arnott-Small 1998; Fujita 1989; Harvey 1996; Henderson 1996a). Az eltérő alapokon álló irányzatokat két típusba sorolhatjuk: a településtudomány (városökológia) és a városgazdaságtan szemléletére támaszkodó megközelítések.

A településtudomány és társtudományai müvelői a gyakorlatban megfigyelhető városszerkezetekből kiindulva próbálják leírni és tipizálni a városi területhasználat jellegzetességeit. Három klasszikus városszerkezeti alapmodell jött létre, amelyek mindegyike egy központi városmagból indul ki, de a városmag körüli szerkezetet eltérő módon adja meg (Cséfalvay 1994; Mészáros 2000; Nemes Nagy 1998): a koncentrikus zónákból álló (Burgess nevéhez kötődő) modell, a szektormodell (Hoyt társadalmi rétegekre vonatkozó empirikus felmérésén alapul) és a policentrikus városmodell (Harris és Ulmann várostörténeti szemléletü vizsgálata alapján). A fenti modellek „kombinációjára” is történtek kísérletek, pl. szektorzonális városszerkezet felvetésére (Harvey 1996, 228). Megemlíthető még a latin- 
amerikai városmodell (Griffin-Ford vizsgálata alapján), amely a fejlődő országok nagyvárosaira jellemző, valamint a délkelet-ázsiai városszerkezet (McGee modellje), amely a gyarmati kikötővárosokból kifejlődött városoknál figyelhető meg (Stutz-de Souza 1998, 288-291).

A valóságban az elméleti modellek „tisztán” ritkán alakulnak ki, mivel a városok szerkezetét a domborzat, a városépítészet gyakorlata, a település nagysága és múltja, etnikai összetétele stb. is befolyásolja. Az is lényeges, hogy a városok szerkezete mindig változik, föleg az urbanizációs ciklusokkal (és hátterükben a gazdasági növekedéssel, a közlekedés változásával stb.) hozhatók összefüggésbe, azonban nem hagyható figyelmen kívül a vizsgálatok fogalomrendszere sem (Berényi 1997; Enyedi 1988; 1996; Lados 1994). A magyar városok szerkezete is többféle (érdekes példaként adódik Budapest városszerkezete), amelyet befolyásolt a települések múltja, a globalizációhoz és rendszerváltáshoz kapcsolódó gazdasági szerkezetváltás (privatizáció), a közlekedési rendszer átalakulása, az innovációk terjedése stb. (Beluszky 2000, 62; Barta 1998; Enyedi 2000; Rechnitzer 1993; 1998a; TimárVáradi 2000).

A fentiekkel ellentétben a városgazdaságtan, mint a közgazdaságtudomány része a városi területhasználatnak nem gyakorlati, hanem elméleti jellegü kérdéseivel foglalkozik: vajon a városokban a területhasználat véletlenszerúen formálódik-e? Ha nem, akkor a közgazdaságtan fogalmaival és módszertanával leírhatók-e a városi területhasználat alapvető gazdasági törvényszerüségei?

A városgazdaságtan a szokásos közgazdasági fogalmak (ár, mennyiség) mellé bevezeti a városi területet, mint endogén változót, ezáltal a gazdaság térbeli kiterjedése kerül a vizsgálatok középpontjába. Kiinduló feltételezése szerint a városi földterület szükös tényezö, amelynek allokációja az árrendszeren keresztül valósul meg, így a föld, mint a gazdasági tevékenységhez szükséges terület használatát annak kereslete és kínálata szabályozza az árakon keresztül. Fő kérdés, hogy a városi terület milyen eloszlása, azaz milyen jellegü területhasznosítás hoz létre térbeli egyensúlyt (Pareto-i értelemben)? Másképpen, egy városi társadalom mennyire hatékonyan hasznosítja a rendelkezésére álló földfelszínt, azaz a társadalom optimálisan használja-e ki a városi területet?

A városi területhasznosításnak van néhány egyedi jellemzője, a legfontosabbak:

- Szükös jószág, viszont szinte korlátlanul megosztható: emeletes házakat (toronyházakat) építve egy-egy felhasználóra a földfelszín igen kicsiny része jut.

- Immobil tényezö: a városi terület nem szállítható, nem vihető máshová, hanem a „használónak” kell odatelepülnie.

- A városi terület bérleti díját föleg elérhetősége határozza meg: a piactól, az üzleti partnerektől, a munkahelytől való távolság és a felmerülő szállitási (közlekedési) költségek.

- Helyettesithetöség áll fenn: a munka, a töke és a terület (nagysága, elhelyezkedése) egymással helyettesíthető termelési tényezők.

A városgazdaságtanban a legismertebb az ún. monocentrikus városmodell, amelynek lényege, hogy egyetlen városközpont létét feltételezzük: itt található a pontsze- 
rü piac, valamint körülötte a kereskedelmi és szolgáltató cégek többsége. Ezt az üzleti negyedet veszi körbe a feldolgozóipari termelővállalatok (munkahelyek) zónája, amely körül helyezkedik el a lakóövezet. A monocentrikus városmodellt Alonso dolgozta ki 1964-ben, felhasználva Burgess modelljét és továbbfejlesztve Thünen mezőgazdasági földhasználatra vonatkozó elméletét (Alonso 1964; BartkeIllés 1997; Lengyel 1994; Varga 2002). Thünen a várost pontszerünek feltételezte, csak a város körüli termőföldek mezőgazdasági hasznosításával foglalkozott. Míg Alonso a városközpontot vette „,pontnak” és a környező területek bármilyen jellegü hasznosítását (nemcsak mezőgazdasági célút) modellezte: az üzleti (ipari, kereskedelmi stb.) vállalkozások mellett a háztartások viselkedését is.

Thünen, illetve nyomdokain Weber, Lösch és Alonso, valamint napjainkban Krugman is egyetlen pontszerü piacot vett figyelembe, így tudták mérhetővé tenni és tudományosan igazolni a gazdaság müködésének alapvető térbeli összefüggéseit. A gazdaság térbeli müködésének modellezésére több kísérlet történt, a pontszerü piac feltételezése az egyik legegyszerübb, de igen jól alkalmazható feltétel, ami a térgazdaságtan archimédészi pontjává vált. A monocentrikus városmodell nem egy világképlet, nem a valóság összes tényezőjének hű leírására szolgál, hanem egyszerü feltételek mellett általános gazdasági összefüggéseket ír le, amelyek alapján a fontosabb közgazdasági törvényszerüségek (pl. térbeli egyensúly) vizsgálhatók és az állítások tudományosan igazolhatók.

A monocentrikus városmodell a gyakorlatban túl egyszerünek és életidegennek tünik, ugyanakkor általános az egyetértés a témakörrel foglalkozó mértékadó, Nobel-díjas közgazdászok között abban, hogy ez a modell az összes lényeges kapcsolódó kutatási kérdéshez hasznos kiindulópontul szolgálhat. Samuelson kiemeli, hogy a Thünen-i földhasználati modell egy térbeli általános egyensúlyelméletnek felel meg, Thünennek szerinte méltó helye van Walras, Mill és Adam Smith mellett a „Pantheon”-ban (Samuelson 1983, 1482). Solow is számos munkájában foglalkozott a városgazdaságtan alapkérdéseivel, sőt a hetvenes évek elején a modern közgazdaságtan egyik legizgalmasabb kérdéskörének tartotta a városi területhasználat egyensúlyi kérdéseinek vizsgálatát (Solow 1973a). Szerinte ,a legtöbb elméleti városmodell monocentrikus és körgyürüs; egy realisztikusabb, különféle foglalkoztatási és alternatív bevásárlói központokkal, rekreációs körzetekkel rendelkező modellben a területhasználat egyensúlyi modellje ugyan jóval komplikáltabb lenne, de az általános alapelv ugyanaz maradna" (Solow 1973b, 602).

A Thünen gondolataira épülő monocentrikus modell képezi egyik alapját Paul Krugman „új gazdaságföldrajzának” (new economic geography) is, ahol a térbeli koncentrációt formáló centripetális erők hatására a feldolgozóipar városokban tömörül, s a kialakuló öngerjesztő hatást pozitív externáliák erősítik (Krugman 2000a). Nyilván egyetlen pontszerü piac feltételezése csak elméleti vizsgálatokra ad lehetőséget, de ,a városgazdaságtan müvelői természetesen tudatában vannak e korlátoknak; így a gyakorlatban mindig kiegészítették Thünen modelljét az agglomerációnak legalább egy vázlatos, a külső gazdasági hatásokon alapuló elméletével" (Fujita-Krugman-Venables 1999, 18). 
Az Alonso-féle monocentrikus városmodell kiindulópontjai: a homogén térben (síkon) egyetlen várost vizsgálunk, amelyben egyetlen (a városközpontban levő) pontszerü piac működik, ahová a termelők (vállalatok) termékeiket szállítják. A városi területen helyezkednek el a vállalatok (ipari, kereskedelmi, pénzügyi stb. cégek) telephelyei, illetve a háztartások lakóterületei. Egy adott területet csak egyetlen cég vagy háztartás használhat (bérelhet). A vállalatoknál és a háztartásoknál egyaránt felmerülnek szállítási, közlekedési, valamint területhasználati költségek (ingatlanbérlet). A vállalatok szállitási költségei a telephely és a pontszerü (egyetlen) piac között, a háztartások közlekedési költségei a lakóhely és a munkahely (telephely) között merülnek fel, mindegyik szállítás (közlekedés) a piacpontból kiinduló egyeneseken (sugarakon) folyik (a közlekedés egyébként bárhol lehetséges). Mindegyik döntéshozót racionálisnak feltételezzük: azon a helyen és akkora területet próbál bérelni, ahol és amekkora a vállalat maximális profitjához, illetve a háztartás maximális hasznossági szintjének eléréséhez szükséges.

Kérdés, hogy a fenti feltételek mellett a városon belül hol folynak a gazdasági tevékenységek, hol lesznek és mekkora területet foglalnak el a vállalati telephelyek, illetve a lakások? Vajon léteznek-e a városi területhasználatnak (ingatlanpiacnak) törvényszerűségei, megadható-e, s ha igen, hogyan, a városi területhasználat egyensúlyi modellje? Milyen térbeli összefüggései vannak az ingatlanok keresletének és kínálatának, leírható-e ezek segítségével a városszerkezet?

A monocentrikus városmodellben mind a vállalatok, mind a háztartások rendelkeznek a bérleti díjra vonatkozóan egy ajánlati bérleti díj függvénnyel (BRC: bid rent curve, vagy bid-rent function, illetve elöfordul: rent-offer curve). Ez a függvény azt adja meg, hogy a vállalatok gazdasági profitjukat zérusnak feltételezve, egy adott helyen lévő terület egységnyi részének használatáért mekkora bérleti díjat képesek fizetni, figyelembe véve a szállítási költségeket is (Anas-Arnott-Small 1998; Pearce 1993). Hasonlóan a háztartások BRC-függvénye azt mutatja, hogy a háztartások hasznosságukat ugyanakkorának véve, egy adott helyen lévő terület egységnyi részének használatáért mekkora bérleti díjat képesek és hajlandók fizetni, figyelembe véve a közlekedési költségeket is. Minél közelebb van egy terület a piachoz (városközponthoz), annál nagyobb bérleti díjat tudnak érte ajánlani a vállalatok és a háztartások, mivel csökkennek a szállítási (illetve a munkába járási) költségek.

A monocentrikus modellnél tökéletes piacot feltételezünk, mindenki árelfogadó és racionálisan dönt, csak a költségei alapján kalkulál (és azonnal költözik, ha változnak a piaci feltételek). Továbbá állandó skálahozadékból indulunk ki, így a termelés mennyiségének változása nem befolyásolja az egységnyi terület bérleti díját. A fenti feltételezések mellett bizonyítható, hogy egy adott ingatlant az a vállalat, avagy háztartás bérel, aki a legnagyobb bérleti díjat tudja ajánlani érte, így a városi terület kereslete és kínálata egyensúlyba kerül: ez a modell egy térbeli egyensúlyi modell (Fujita-Thisse 2002).

A BRC-függvény lényegében a vállalatok vagy háztartások ,közömbösségi görbéje" a területegységre jutó bérleti díj és a szállítási (közlekedési) költség alapján 
(amelyek összege állandó). A BRC-függvények eltérőek a gazdasági tevékenységek jellege (elérhetőség, szállításigényesség), valamint a háztartások típusai szerint is, azaz a tevékenységtől (jövedelemtől) függően a vállalatok (háztartások) különböző nagyságú bérleti díjat képesek felajánlani. Ebben az elméleti modellben földterület alatt a földfelszín egy adott részét értjük, így például a toronyházak esetében - ahol az emeleteken nagyon sok cég bérelhet irodát - amekkora arányban használ egy vállalat irodákat az összes emeletet figyelembe véve, olyan arányban részesül az alapterületböl (földfelszínből).

Tanulmányunkban először a vállalatok által kifizethető bérleti díjakkal foglalkozunk, amelyek formalizálására többféle megközelítés ismert (Beckmann 1999). Jelen dolgozatban a területhasználat intenzitására támaszkodva a regionális gazdaságtanban használatos egyik alapvető levezetést ismertetjük (Hoover-Giarratani 1999, 6. fejezet). A háztartásoknál Alonso munkájából indulunk ki, de támaszkodunk a később született eredményekre is (Alonso 1964; Fujita 1989; 1996; FujitaThisse 2002; Harvey 1996; McCann 2001).

\section{A területhasználat intenzitása}

A területhasználattal kapcsolatos térbeli egyensúly kulcskérdése: hogyan írhatók le és hogyan jellemezhetők az ajánlati bérleti díj függvények? A vállalati BRCfüggvények modellezése többféleképp elvégezhető, pl. termelési függvényekre visszavezetve (Beckmann 1999; Solow 1973a). A regionális gazdaságtanban Hoover megközelítése általánosan elterjedt, aki lényegében a területhasználat intenzitásából (land use intensity) indult ki, amely alatt az egységnyi földterületre jutó kibocsátást (hozzáadott értéket) értjük (Hoover-Giarratani 1999). Nyilván nemcsak mezőgazdasági, hanem bármilyen gazdasági tevékenységet végezhetünk egy adott földterületen (kivéve néhány „helyhez kötött” tevékenységet). Kérdés: egy adott helyen mekkora az egységnyi földterületre jutó optimális kibocsátás, figyelembe véve a központtól (a piactól) való távolságot is? Ez a kérdés ekvivalens azzal, hogy egy adott helyen milyen jellegü gazdasági tevékenységet célszerủ végezni, avagy hol béreljen egy meghatározott profilú cég területet (ingatlant, telket) a telephelyének?

A korábban írottakkal összhangban a következőkből indulunk ki:

- Tökéletes versenyt feltételezünk: sok hasonló tevékenységi körủ vállalat müködik, amelyek tökéletesen informáltak, racionálisan döntenek és árelfogadók, a föld (terület) korlátozás nélkül, szabadon adható-vehető (és bérelhető).

- A szállitás minden irányban lehetséges (a pontszerü piac és bármely földterület közötti egyenesen): nincsenek természeti akadályok, lényegében egy homogén síkról van szó.

- Zárt modellt veszünk alapul: egyrészt adott a vállalatok és a lakosság száma (nincs migráció és nincs ingázás), másrészt a városban képződő jövedelmek helyben maradnak, nincs városon kívüli kereskedelem, illetve a városi terület tulajdonosai és bérlői eltérnek egymástól. 
Tegyük fel, hogy egy vállalatnál az egységnyi területre számított összes termelési költséget (TC, total cost) az alábbi összefüggés írja le (Hoover-Giarratani 1999, 6. fejezet):

$$
T C=F+a Q^{b} \quad F>0, a>0 \text { és } b>1,
$$

ahol $\quad F$ az egységnyi területre jutó fix költség,

$Q$ az egységnyi területre jutó kibocsátás (output),

$a$ és $b$ a technológiát ('́gy az adott gazdasági tevékenységet) leíró paraméterek (konstansok).

A BRC-függvény jellemzéséhez induljunk ki egy olyan vállalatból, amely egyetlen terméket állít elő, a piacpontban ezen termék egységára: $p$. Jelölje $t(x)$ az egységnyi termék szállítási költségét a telephelytől a piacra, ahol $x$ a vállalati telephely távolsága az adott pontszerủ piactól, a szállítási költséget leíró függvény pedig szigorúan monoton. A vállalat gazdasági profitja zérus, a tökéletes verseny miatt a földjáradék pedig egyenlő a bérleti díjjal. Így a vállalati árbevételre teljesül:

$$
\text { árbevétel }=\text { termelési költség + szállitási költség + bérleti dij (földjáradék) }
$$

Ekkor a piactól $x$ távolságra levő egységnyi terület használatáért a vállalat által fizetett $R$ bérleti díj a $Q$ mennyiségü termék után elért árbevétel és az összes (termelési és szállítási) költség különbsége:

$$
R(x)=p Q-F-a Q^{b}-t(x) Q
$$

Kérdés, hogy egy adott ( $a$ és $b$ paraméterü) tevékenység esetén milyen kibocsátási szint $(Q)$ mellett érhető el és mekkora lehet a maximális bérleti díj $(R)$ ? A vállalati BRC-függvényt a (2) kifejezés írja le, amelyről feltesszük, hogy kétszeresen differenciálható mind a piactól való távolság $(x)$, mind a kibocsátás $(Q)$ szerint.

Nyilvánvalóan a technológiai paraméterektől függő optimális kibocsátási szint mellett lehet a legnagyobb bérleti díjat megajánlani. A kibocsátási szint elemzéséhez a (2) BRC-függvény szélsőértékét kell megvizsgálnunk, amelyhez a $Q$ szerinti első és második deriváltakat használhatjuk:

$$
\begin{gathered}
d R / d Q=p-a b Q^{b-1}-t(x) \\
d^{2} R / d Q^{2}=-(b-1) a b Q^{b-2}<0
\end{gathered}
$$

A második derivált negatív, mivel $b>1$ feltételünk van, így ahol az első derivált nulla, ott van a vállalati BRC-függvénynek szélsőértéke:

$$
p-a b Q^{b-1}-t(x)=0
$$

amiből átrendezéssel adódik a szállitási költségtől, így a távolságtól $(x)$ függő optimális kibocsátás (ahol az $R$ maximális): 


$$
Q(x)=[(p-t(x)) / a b]^{1 /(b-1)}
$$

A fentiek alapján egy adott terület optimális kibocsátása nemcsak az ott tevékenységet végző vállalat technológiai paramétereitől függ, hanem a szállítási költségektől, azaz a piactól (városközponttól) való távolságtól is. Egyszerüen belátható, hogy a (3) függvény értéke a piacponttól (az origótól) távolodva csökken.

Adott $x$ helyen ennek a vállalatnak (gazdasági tevékenységnek) BRC-függvényére, a maximálisan ajánlható bérleti díjat kifejező $R(x)$ függvényre adódik a (3) optimális kibocsátást (2)-be behelyettesítve és egyszerüsítve:

$$
R(x)=a(b-1)[(p-t(x)) / a b]^{b /(b-1)}-F
$$

Kérdés, hogyan változik a vizsgált vállalat maximálisan ajánlható $R(x)$ bérleti díja a piactól való $x$ távolság függvényében? Az egyszerüség kedvéért tegyük fel, hogy $t(x)$ lineáris, jelölje $t$ az egységnyi termék egységnyi távolságra jutó szállítási költségét, így $t(x)=t x$. A (4) függvény szélsőértékét vizsgálva az $x$ szerinti deriváltak segítségével:

$$
\begin{gathered}
d R / d x=-\operatorname{tab}[(p-t x) / a b]^{1 /(b-1)}<0 \\
d^{2} R / d x^{2}=\left[t^{2} a b /(b-1)\right][(p-t x) / a b]^{(2-b) /(b-1)}>0
\end{gathered}
$$

A fentiek alapján az $R(x)$ ajánlati bérleti díj függvény a piactól távolodva csökkenő lejtésű és felülről konkáv (másképpen alulról konvex). A csökkenő lejtés a modell egyik legfontosabb eredménye, ugyanis bármelyik gazdasági tevékenység esetén a piacponttól távolodva egyre kisebbek lesznek az egységnyi területre megajánlható bérleti díjak (Anas-Arnott-Small 1998).

A különböző gazdasági tevékenységeket végző (egytermékes) vállalatok eltérö paraméterekkel $(F, a, b$ és $t)$ rendelkeznek, mindegyikhez megadható a megfelelő BRC-függvény, így nagyon sok különbözö lejtésü függvény rajzolható fel, amelyek metszhetik egymást. Az egyes paraméterekre vonatkozóan a (4) BRC-függvényt vizsgálva adódik (Hoover-Giarratani 1999, appendix 6-1):

- ha $a$ és/vagy $b$ értéke magas ( $F$ és $t$ átlagos), akkor kevésbé lesz meredek a BRC-függvény, azaz a vállalatok ilyen jellegű tevékenység esetén a városközponttól távolabb bérelhetnek területet,

- ha $F$ és/vagy $t$ értéke magas ( $a$ és $b$ átlagos), akkor meredekebb lesz a BRCfüggvény, mivel magas a rezsi, avagy szállításigényes a tevékenység, így ezek a vállalatok a városközpontot részesítik előnyben.

Az a vállalat tudja kibérelni a központtól $x$ távolságra levő egységnyi területet, amelynek $R(x)$ függvénye abban a pontban a legnagyobb értékkel bír, azaz amelyik a legmagasabb bérleti díjat képes megajánlani. A monocentrikus modellben a hasonló tevékenységü (hasonló BRC-függvényü), a területet hasonló intenzitással hasznosító vállalatok nagyjából egyforma távolságra helyezkednek el a városközpont körül, ezáltal egy csökkenö lejtésü aggregált BRC-függvény adható meg (amely az egyedi cégek BRC-függvényeinek burkológörbéje). Az aggregált BRC- 
függvény folytonos és monoton csökkenő, de bizonyos szempontok alapján szakaszokat (az értelmezési tartományban intervallumokat) képezhetünk, így a városközpont körül hasonló bérleti díjú, nagyjából homogén tevékenységü koncentrikus körök, zónák adhatók meg. A városközpontban található a terület legintenzívebb hasznosítása, olyan tevékenységek kerülnek oda, amelyek kevésbé területigényesek és egységnyi területre jutó kibocsátásuk a legnagyobb. A városközponttól távolabbra kerülnek a kibocsátáshoz nagyobb területet igénylők, míg legtávolabb, a városhatáron túl a mezőgazdasági hasznosítású földterületek vannak.

A közgazdaságtan vizsgálódási területe itt véget ér, így a városgazdaságtané is, mivel a monocentrikus modell empirikus tesztelésekor részben a kiinduló feltételek nagyobb része nem teljesül, részben gazdaságon kívüli szempontok is felmerülnek (értékelésükre a dolgozat további részein térünk ki). Nyilván egy-egy modell akkor ér valamit, ha visszaigazolja az élet, ezért igen sokan megpróbálták tesztelni a gyakorlatban a fent leírtakat.

Az empirikus vizsgálatok szerint, amelyeket föleg „új alapítású városok” esetén végeztek el (ahol a városi területnek, mint termelési tényezőnek a piaci adásvétele kevésbé akadályozott, mint a történelmi városokban), a zónákat meg lehet különböztetni a dominánsnak tekintett tevékenység, azaz gazdasági szektor szerint. Többféle szektort szokás elkülöníteni, de ezek mindegyike csak nagyon durván közelíti a valóságot, mivel egyetlen szektor sem homogén, pl. a kereskedelmen belül is nagyon sokféle eltérő egység van, más egy ékszerbolt, egy cipőbolt, egy élelmiszerbolt, egy autókereskedés stb. BRC-függvénye, de pl. a cipőboltok esetében is eltéröek a márkás divatcipők és a távol-keleti tömegcipök városon belüli árusítóhelyei. Harvey a boltok következő sorrendjét emelte ki a városközponttól távolodva: komplex áruház, női divatáru, fényképezőgépek (kamerák), cipőbolt, női ruházat, ékszerek, bútorok, férfi ruházat stb. (Harvey 1996, 220). Hasonlóan egy bankközpont általában a városközpontban van, ahol magas a bérleti díj, míg a bankfiókok a város területén szétszórva, közel az ügyfelekhez és jóval olcsóbb ingatlanokban. A fentiek miatt egy-egy gazdasági szektor csak nagyjából jelzi, hogy milyen tevékenység tudja optimálisan hasznosítani azt a területet, továbbá a zónák határa sem egy vonal, hanem egy széles sáv.

A monocentrikus modell hagyományos leírásában két gazdasági szektort szokás megkülönböztetni (csak profit-orientált tevékenységeket tekintve), amelyek egymást követő zónákban helyezkednek el (Straszheim 1987; Johnston et al 2000; Lengyel 1994, 57; Stutz-de Souza 1998, 285): a kereskedelmi zónát (commercial vagy retailing) és az ipari zónát (industrial vagy manufacturing), amelyet követően található a mezőgazdasági hasznosítású földterület (már nem városi terület).

Az egycentrumú városoknál, napjaink valóságát is alapul véve, több variánst dolgoztak ki a gazdasági szektorok elkülönítésére és sorrendjére (McCann 2001). Véleményünk szerint leginkább a négyszektorú felosztás helytálló, amelynek egymást követő zónáit egy koordinátarendszerben ábrázolhatjuk, ahol az origóban van a piacpont, függőlegesen az egységnyi területért ajánlott bérleti díj, vízszintesen pe- 
dig a piactól való távolság (1. ábra). A szektorok aggregált BRC-függvényeinek metszéspontjai egyúttal a zónák határai:

- Üzleti szolgáltatás: bankok és biztosítók központjai, nívós szállodák és éttermek, elegáns üzletek, ügyvédi és könyvelő irodák, befektetési tanácsadók, tervező és marketing cégek stb. Ezek a szolgáltatók általában többszintes irodaházakban müködnek és a város egész területéröl várnak üzleti partnereket.

- Lakossági szolgáltatás: főleg kiskereskedelem, háztartási gépek javítása, fodrászat, olcsóbb szállodák és éttermek stb., amelyek elsősorban emeletes házak földszintjén találhatók, a fogyasztók kisebb részét látják el, akikhez közel települnek.

- Feldolgozóipar: nagyobb helyigényü, általában földszintes épületekben müködő üzemek.

- Logisztikai szolgáltatás: nagy területet használó raktárak, szállítmányozó cégek telepei (parkolói), bevásárlóközpontok stb.

\section{1. ÁBRA}

A profit-orientált tevékenységek föbb zónái

(Main Zones of Profit-oriented Activities)

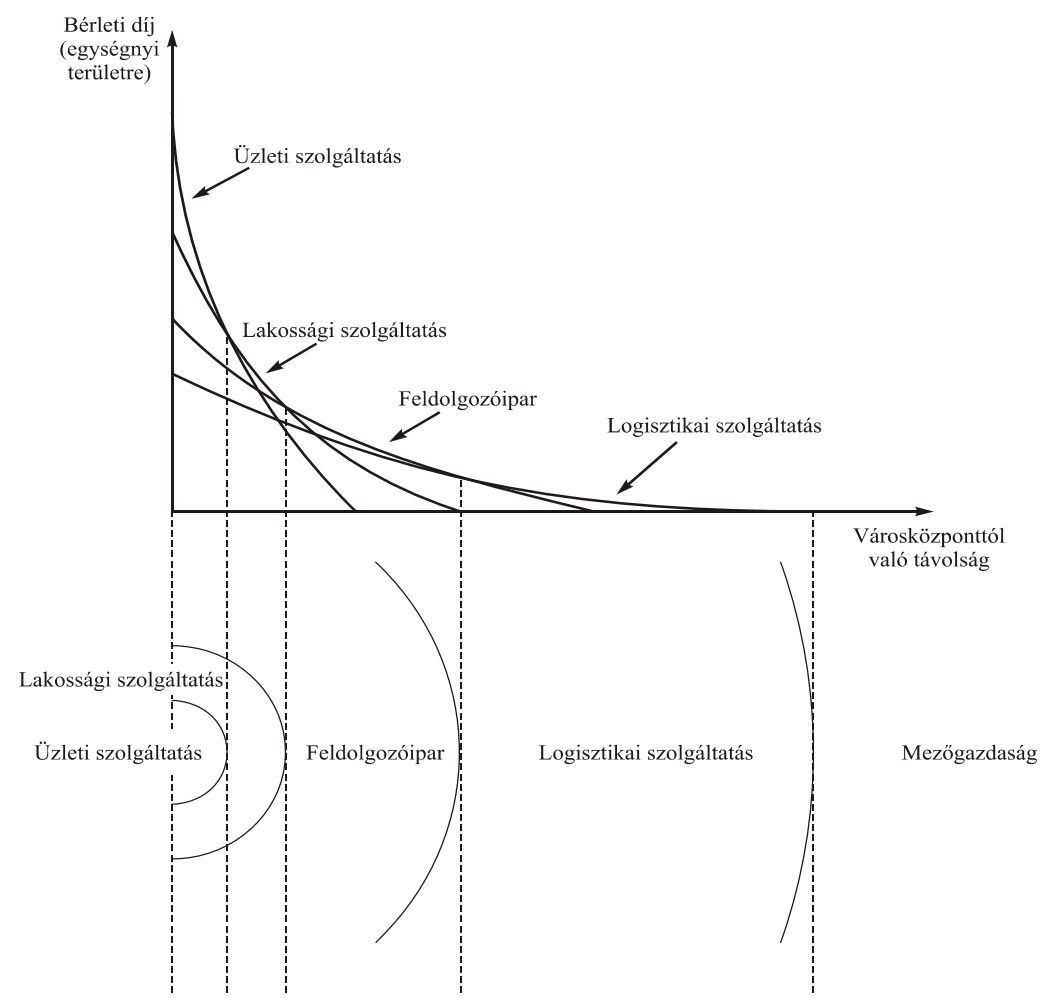

Forrás: McCann $(2001,106)$ alapján saját szerkesztés. 
Az egyes szektorok BRC-függvényeinek meredeksége eltérő, illetve megadható az a távolság, amelynél messzebb ezt a tevékenységet nem célszerú végezni, mivel a magas szállítási költségek miatt veszteség képződik. A szolgáltatásokra jellemző, hogy magas a rezsiköltség $(F)$ és viszonylag alacsony az egy termékegységre jutó változó költség (amelynek nagyobb része bérköltség), emiatt meredek a BRCfüggvényük. A feldolgozóiparban nagyon sokféle tevékenységet végeznek, de az egységnyi hozzáadott értékre jutó szállítási költség kevésbé magas. Nyilván egy feldolgozóipari vállalatnak a város több pontján lehetnek részlegei, a városközpontban a vezérigazgatósága, míg távolabb az üzemek. A logisztikai (részben nagykereskedelmi) szolgáltatásoknál fontos az is, hogy viszonylag nagy összefüggő területet igényelnek.

A fenti négy szektor BRC-függvénye érzékelteti, hogy jelentős átfedés lehet a szektorok között. A szektorok megnevezése is elnagyolt, csak nagyjából jelzi, hogy milyen jellegü tevékenységek relatíve mekkora bérleti díjat képesek fizetni. Az üzleti szolgáltatásoknak helyet adó városközpontot $C B D-n e k$ szokás nevezni $(C B D$ : central business district), ahol a legmagasabbak a bérleti díjak (a vállalatok BRCfüggvényei ott a legmeredekebbek).

A területhasznosítás intenzitását alapul véve, nagyon egyszerü feltételekböl kiindulva is igazolható, hogy a városi területhasználatnak kimutathatók bizonyos közgazdasági törvényszerüségei. A monocentrikus modellben a bérleti díjak a városközponttól távolodva csökkennek és megadhatók a városközpont körül a hasonló gazdasági tevékenységek zónái. A városi területhasználatnak ez egy egyensúlyi modellje, azaz a társadalom számára az ajánlati bérleti dijakon alapuló térfelosztás a legkedvezöbb, amely Pareto-hatékony. Természetesen a figyelembe vett feltételek sokszor nem érvényesülnek a valóságban, egy-egy város nemcsak gazdasági egység, hanem jóval több annál, amely szempontokra majd később térünk ki.

\section{A háztartások ajánlati bérleti dij függvényei}

A vállalatok mellett a városi ingatlanpiac másik szereplőcsoportját a háztartások képezik. A háztartások viselkedését ugyancsak az Alonso-féle monocentrikus modellben fogjuk megvizsgálni, a korábban is felhasznált általános feltételek mellett: tökéletes verseny, a közlekedés egyenes vonalú, a háztartás jól informált és racionálisan dönt stb.

A háztartások területhasználati döntései modellezésének megértéséhez tegyük fel, hogy egy városba új család érkezik és lakást keres. A család adott (fix) jövedelemmel rendelkezik, amit alapvetően két célra használ fel: ingatlannal kapcsolatos kiadásokra és egyéb fogyasztási javakra. Az ingatlan kiválasztásánál két szempont merül fel: az ingatlan nagysága (alapterülete), valamint a központtól való távolsága a közlekedési költségek miatt. Feltételezzük, hogy háztartásonként egyetlen keresö családtag van, így egyetlen munkába járási költség merül fel, az egyszerüség végett a városközpontban van a munkahely. Lényegében a család három paraméter alapján 
mérlegel: egyéb fogyasztási javak fogyasztásának nagysága, az ingatlan elhelyezkedése (távolsága a centrumtól), valamint az ingatlan nagysága.

Ha a család a centrumtól $x$ távolságra választ $h$ nagyságú lakást (ingatlant), akkor a monocentrikus városmodell feltételeiből kiindulva a háztartás költségvetési korlátja (fix összes jövedelmet alapul véve) a következő szerkezetü (Alonso 1964; Anas-Arnott-Small 1998; Fujita-Thisse 2002):

$$
y=z+R(x) h+t(x)
$$

ahol: $\quad y$ a rendelkezésre álló (fix) jövedelem, $z$ az egyéb fogyasztási javakra szánt összeg, $R(x)$ a centrumtól $x$ távolságra levő egységnyi terület (lakás) bérleti díja, $h$ a bérelt terület (lakás) nagysága, $t(x)$ a munkába járás (a centrumba utazás) költsége, amely $x$ szigorúan monoton növekvő függvénye.

A család döntési problémája a következö: mivel a jövedelem adott, ezért vagy a központhoz közeli lakást választanak, ekkor kisebb ugyan a közlekedési költség, viszont magasabb a bérleti díj, és így várhatóan kisebb lakást bérelhetnek, vagy kevesebb pénzük marad egyéb fogyasztási javakra. Távolabbi lakást is bérelhetnek, ekkor viszont megnőnek a munkába járás költségei, de a kisebb bérleti díjak miatt nagyobb lehet a lakásuk, vagy megnőhet az egyéb fogyasztásuk. Alonso ezt a problémát a három mérlegelési szempont: $z, h$ és $t(x)$ közötti kapcsolatokra vezette viszsza, részben páronként elemezte az összefüggéseiket (mint közömbösségi görbéket), részben háromdimenziós közömbösségi felületeket vizsgált (Alonso 1964, 18$35)$.

Ha a városközponttól való távolság szerepét elemezzük, akkor a háztartások által realizált $U$ hasznossági szint az ingázási költségekkel csökkentett jövedelemböl megvásárolható fogyasztási javak $z$ mennyiségétől és az általuk igénybevett lakóterület $h$ nagyságától függ. Ekkor az ingatlan kiválasztásánál (mivel az egyéb fogyasztás adott) két szempont játszik szerepet: az ingatlan nagysága (alapterülete), valamint a központtól való távolsága. Valamennyi jószágról - így a lakóterületről is - feltételezzük, hogy határhasznuk pozitív és csökkenő. A fogyasztási javak egységára legyen egységnyi, így $z$ nem csupán a fogyasztási javak mennyiségét, hanem a rájuk költött összeget is méri.

Jelölje a család (háztartás) hasznossági függvényét $U(z, h)$, ekkor a háztartás célja:

$$
\max _{z, h} U(z, h), \quad \text { feltéve, hogy } z+R(x) h=y-t(x)
$$

ahol $y-t(x)$ a központtól $x$ távolságra realizálható nettó (az ingázási költségekkel csökkentett) jövedelem. A preferenciákat és a jövedelem nagyságát illetően a háztartásokat egyformáknak feltételezzük, ezért az egyensúlyi helyzetben, a használt ingatlan helyétől függetlenül, valamennyiüknek ugyanazt az $\bar{u}$ hasznossági szintet kell elérniük. 
A háztartások $R(x, \bar{u})$ BRC-függvénye megadja, hogy a háztartás mekkora maximális összeget képes ajánlani a központtól $x$ távolságra levő egységnyi területért egy adott $\bar{u}$ hasznossági szint mellett, amit az egyéb fogyasztási javakra költött összeg $(z)$ és a lakás nagysága $(h)$ határoznak meg. A döntési feladat ekkor a következőképpen formalizálható (Anas-Arnott-Small 1998):

$$
R(x, \bar{u})=\max _{z, h}\left\{\frac{y-t(x)-z}{h} \quad \mid U(z, h) \geq \bar{u}\right\}
$$

Kérdés, hogy hol lehet lakást bérelni adott preferenciarendszer és hasznossági szint esetén? Az $R(x, \bar{u})$ BRC-függvény viselkedését a városközponttól való távolság szerint vizsgálva az $x$ szerinti derivált $(\bar{u}$ fix):

$$
\frac{d R(x, \bar{u})}{d x}=-\frac{t^{\prime}(x)}{\bar{h}(y-t(x), \bar{u})}<0
$$

ahol $\bar{h}(y-t(x), \bar{u})$ a (6) optimális megoldása. Mivel az első derivált negatív, a háztartások által ajánlott bérleti díj a piactól (centrumtól) távolodva csökkenő, hasonlóan a profit-orientált vállalkozások függvényeihez. Belátható, ha $t(x)$ függvény legalább lineáris, azaz az ingázási költségek a távolsággal arányosan vagy annál nagyobb arányban nőnek, akkor a háztartások BRC-függvényei alulról konvexek (Fujita-Thisse 2002).

A különböző háztartások BRC-függvényeinek meredeksége eltérő, mivel eltérőek a preferenciáik is (nagyobb lakás vagy több egyéb fogyasztási cikk). Egy adott területet az foglalhat el, aki a legnagyobb bérleti díjat ajánlja érte. Egy háztartás végül is ott bérel ingatlant, ahol a BRC-függvénye érinti az összes háztartás BRCfüggvényeinek burkológörbéjét (aggregált BRC-függvényét). Az aggregált BRCfüggvény folytonos és csökkenő lejtésű, de a hasonló preferenciájú háztartásokat figyelembe véve, amelyek a városközpont körül nagyjából egyforma távolságra bérelnek lakást, bizonyos típusok kijelölhetők, ezáltal koncentrikus körök, zónák adhatók meg.

A háztartások BRC-függvényei alapján történő tipizáláshoz, és így a zónák megadásához többféle szempontot vehetünk figyelembe (McCann 2001). Az eltérő jövedelmi helyzet a valósághoz közel áll (az y értéke különbözö lehet), azaz megengedjük, hogy a háztartások különbözö jövedelmi osztályokba tartozzanak (ez adódik akkor is, ha több kereső van a családban). Hasonló preferenciák és ingázási költségek mellett ebben az esetben a jövedelem növekedésével az egyes népességcsoportok mind távolabb fognak elhelyezkedni a centrumtól (Fujita-Thisse 2002; McCann 2001). 


\section{2. ÁBRA}

A háztartások zónái jövedelmi viszonyaik alapján

(Zones of Households by Their Income Level)

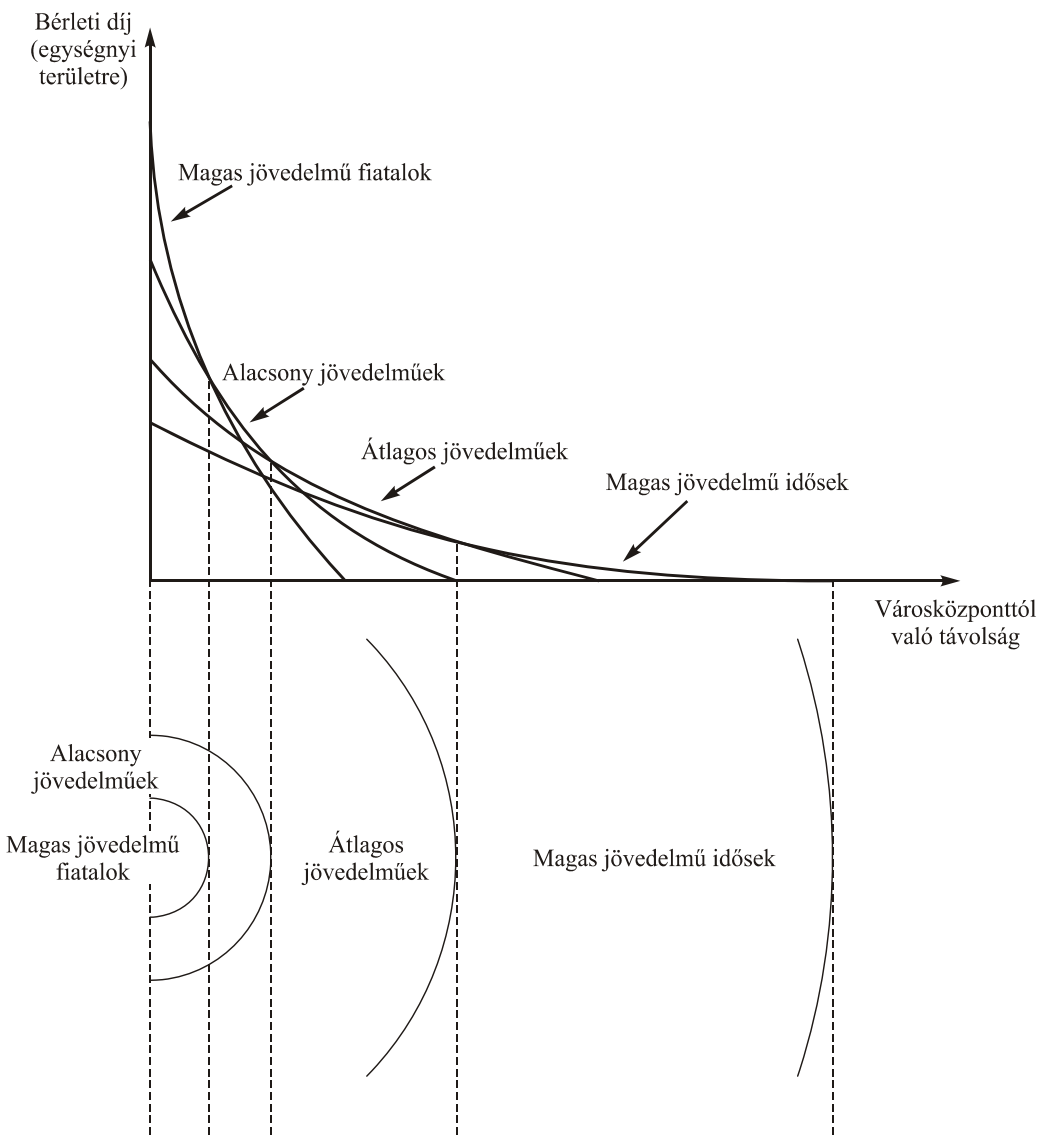

Forrás: McCann $(2001,112)$ alapján saját szerkesztés.

Az eltérő jövedelmek bevezetésével különböző tipizálások végezhetők el, véleményünk szerint négy zónát célszerü megkülönböztetni, amelyek az épületek jellege, a család „életgörbéje” (a családtagok életkora és a jövedelem nagysága), valamint a közlekedés sajátosságai szerint is elkülönülnek (2. ábra):

- Magas jövedelmü fiatalok: akik a városközponthoz (munkahelyhez) közel, viszonylag drága többszintes társasházakban kisebb alapterületü lakást bérelnek, nincsenek gyerekeik, a munkahelyre gyalog vagy tömegközlekedési eszközzel járnak (autó és így garázs sem kell).

- Alacsony jövedelmüek: emeletes lakóházakban (társasházakban), viszonylag kisebb és olcsóbb bérletü lakásokban élnek gyerekeikkel együtt, dolgozni föleg tömegközlekedési eszközökkel járnak, ha van autójuk, akkor sem használják minden nap (garázsuk általában nincs). 
- Átlagos jövedelmüek: nagyobb területủ (kétszintes) sorházi lakásokban, esetleg kisebb telken levő családi házakban élnek gyerekeikkel együtt, autójuk és garázsuk is van, munkába autóval járnak és a gyerekeiket is azzal viszik az iskolába (esetleg átszállnak tömegközlekedési eszközre).

- Magas jövedelmü idösek: nagyobb telken levő családi házakban élnek, a gyerekeik már felnőttek, állandóan autóval járnak dolgozni, illetve inaktív korszakukban ügyeiket intézni.

A fentiekben áttekintettük a monocentrikus modellből kiindulva és egyszerủ közgazdasági feltételeket bevezetve, hogyan formalizálhatók a háztartások területhasználattal (lakásbérlettel) kapcsolatos döntései. A városközpontban a legnagyobb az egységnyi (földfelszínre számolt) terület bérleti díja, majd attól távolodva fokozatosan csökken, viszont egyre nagyobb méretüek lehetnek a lakások is. Ez egy triviális, a gyakorlattal megegyező megállapítás, amely a közgazdaságtan „axiómáit” felhasználva tudományosan igazolhatóvá vált, egyúttal bizonyítva, hogy létezik a háztartások városi területhasználatának egyensúlyi modellje, amely optimális megoldását adja „városi tér” hasznosításának. A gyakorlatban a háztartások döntéseit gazdaságon kívüli szempontok is befolyásolják (lakáspolitika, várospolitika, területrendezés, közlekedés rendszer stb.), amelyek városonként eltérőek lehetnek, és amelyek empirikus elemzése túlmutat a városgazdaságtan kutatási témakörein és átnyúlik a városszociológia, településföldrajz stb. tudományterületekre (Lengyel 1991, 1993).

\section{A háztartások közötti externáliák és a területhasználat}

A háztartásokra jellemző, hogy lakóhelyválasztással kapcsolatos döntéseik során nemcsak jövedelmeiket és az ingatlannal szembeni elvárásaikat, hanem a szomszédságot, a lakókörnyezetet is mérlegelik. A városgazdaságtan is foglalkozik elméleti alapokon ezzel a kérdéskörrel, amelyet a háztartások közötti extern hatások segítségével modellez (Kanemoto 1996; Lengyel-Mozsár 2002).

A külső gazdasági hatás (externália, extern hatás) a közgazdaságtan egyik alapfogalma, azt fejezi ki, hogy a vállalatok vagy egyének tevékenysége azoknak is előnyöket jelenthet, avagy hátrányokat okozhat, akikkel nem állnak üzleti kapcsolatban (Lengyel-Mozsár 2002; Mozsár 2000; Varian 2001). Lényeges, hogy az előnyt élvezők nem fizetnek az előnyök nyújtójának, a hátrányokat elszenvedők pedig nem kapnak kárpótlást a hátrányok okozójától. A külső gazdasági hatásokat az elemzések célja szerint többféleképpen szokás tipizálni, megkülönbözethetünk: pozitív vagy negatív, fogyasztói avagy termelési hatásokat, nem anyagi (technológiai) jellegủ vagy pénzben kifejezésre jutó (pecuniary) externáliákat stb. Alapvető, hogy külső gazdasági hatás esetén eltérhet az egyéni haszon és egyéni költség a társadalmi haszontól és társadalmi költségtől, emiatt közgazdászok sora (többek között Pigou, Mill, Hayek, Coase stb.) foglalkozott azzal, hogy az erőforrásallokáció az externáliák következtében a társadalom számára mennyire hatékony, illetve hogyan tehető hatékonyabbá. Általánosan elfogadott, hogy a magánköltsége- 
ket egyenlővé kell tenni a társadalmi költségekkel (Pigou-féle adózás), ezáltal internalizálni, lényegében megszüntetni lehet az externáliákat, megfelelő adókat kivetve a negatív, míg támogatásokat nyújtva a pozitív extern hatásokat.

A városokban keletkezhetnek negatív vagy pozitív extern hatások a vállalatok és a háztartások (zaj, büz stb.), de ugyanúgy a különböző típusú emberek, embercsoportok (gazdagok-szegények, fehérek-színes bőrüek stb.) között, de származhatnak extern hatások a közvetlen lakókörnyezet állapotából is (lakókörnyezet ápoltsága, éjszakai kivilágítás stb.). A háztartások közötti externáliák modellezése a faji elöitéletek példáján keresztül is érzékeltethető, amelynek meglehetősen bőséges a szakirodalma (nemcsak közgazdasági, hanem szociológiai munkák sokasága elemzi ezt a témakört), és a gyakorlatban is megfigyelhetö a városokban lezajló szegregálódás során (Beluszky-Szirmai 2000; Kanemoto 1996; Lengyel-Mozsár 2002; McDonald 1997; Muth 1996).

A faji előítélet hatását vizsgáló modellekben általában azt feltételezik, hogy a fehérek nem szívesen laknak a színes bőrủek közelében, miközben a színes bőrủek vagy preferálják a fehérek közelségét, vagy közömbösek azzal szemben. Más szavakkal, a fehérekre a közelben lakó színes börüek negatív extern hatással vannak, a színes bőrüekre ugyanakkor a fehérek közelsége pozitív hatással bír, avagy semmilyen hatással nincs.

A faji elöitélet városszerkezetre gyakorolt hatását többféle modellel vizsgálták (Fujita 1996; Harvey 1996; Kanemoto 1996; Lengyel-Mozsár 2002). Ezek közül a legegyszerübb a monocentrikus városmodellből kiinduló ún. határvonal-modell (border model), amelyben feltételezzük a színes börüek és a fehérek lakóhelyei között a teljes szegregációt. A modell abból indul ki, hogy a centrumban a színes bőrủ családok élnek (általában kisebb lakásban nagyobb számú család), s az előítéletek miatt a fehérek preferálják a határvonaltól való nagyobb távolságot (3.ábra).

\section{3. ÁBRA}

Határvonal-modell, amikor a centrumban a szines börüek élnek (Border-line Model if Coloured People Live in the Centre)

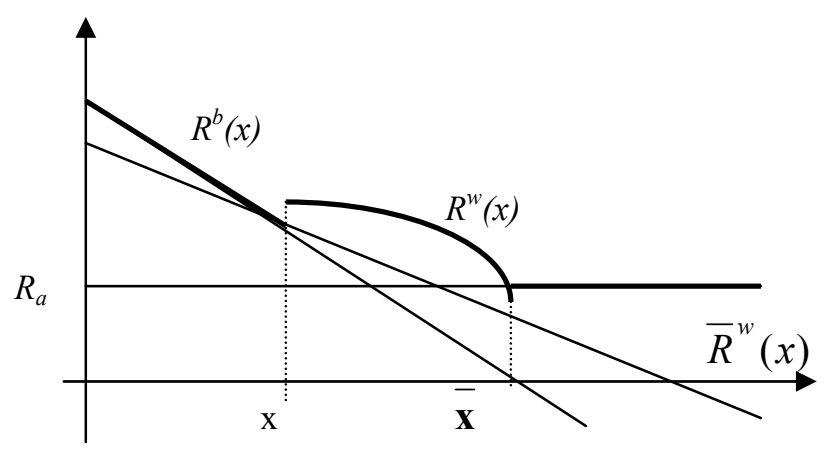

Forrás: Kanemoto (1996, 205) alapján saját szerkesztés. 
A meredekebb $R^{b}(x)$ egyenes a színes bőrủek, az $\bar{R}^{w}(x)$ a fehérek externáliák nélküli BRC-függvénye (az egyszerüség végett egyenessel ábrázoljuk az externáliák nélküli BRC-függvényeket). Továbbá $x^{\square}$ a színes bőrủek lakta zóna határa, $\overline{\mathrm{X}}$ pedig a városhatár, amelynél a bérleti díj megegyezik az adottnak feltételezett $R_{a}$ vidéki bérleti díjjal. Levezethető, ha a fehéreknek elöítéleteik vannak a színes börüekkel szemben, de a színes bőrüek semlegesek, akkor a faji elöitélet megerösiti a szegregációt, mert a fehérek felárat fizetnek a fehér zónán belüli lakhatási lehetőségért, így az extern hatásokat is tükröző BRC-függvényük $R^{w}(x)$ lesz.

\section{4. ÁBRA}

Határvonal-modell, amikor a centrumban a fehérek élnek (Border-line Model if White People Live in the Centre)

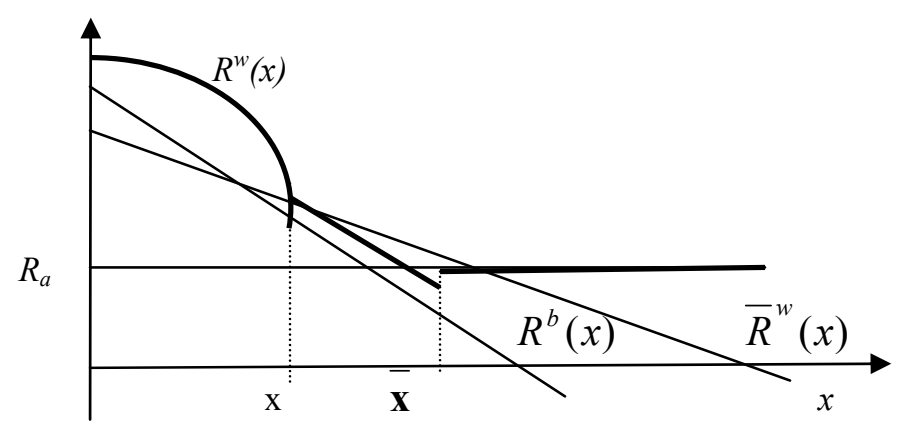

Forrás: Kanemoto $(1996,205)$ alapján saját szerkesztés.

Egyensúlyi lehet az a megoldás is, ha az extern hatás elég erős, amikor a fehérek laknak a belső, és a színes bőrüek a külső zónában (4.ábra). Az externáliák ebben az esetben meredekebbé teszik a fehérek BRC-görbéjét, hiszen ekkor felárat is hajlandók fizetni a zónán belül maradásért.

A fenti gondolatok alapján a faji elöitélet mint externália végsö soron a fehéreket hozza rosszabb helyzetbe, hiszen a határ közelében élök veszteséget szenvednek az extern hatás miatt, a távolabb élök is magasabb díjat fizetnek, mint amilyent extern hatás, azaz elöítélet nélkül kellene fizetniük. Tehát a társadalmat, a közösséget veszteség éri a szegregáció miatt, így a várospolitikának racionális közgazdasági szempontok alapján is arra kell törekednie, hogy mérsékelje, avagy megszüntesse a faji elöitéletekböl származó elkülönüléseket.

Megjegyezzük, ha a háztartások egyik típusát negatív extern hatás éri a háztartások egy másik típusától, akkor nem zárható ki egy erőteljes instabilitás sem, amikor beindulhat egy „szlömösödési” folyamat (,cumulative decay process”, „tipping process"), amely úgy megy végbe, hogy a centrumbeli színes börủ háztartások számának kis növekedése tovább rontja az ott élő fehérek helyzetét, további fehér háztartásokat késztetve ezzel távozásra. Emigrációjuk pedig fölgyorsítja a centrum lerobbanásának folyamatát. Az ehhez kapcsolódó „inner city” problémát és megoldási javaslatot vetett fel Michael Porter, igen élénk vitát kiváltva (Porter 1998). 
A háztartások lakásuk kiválasztásakor nyilván a valóságban kevésbé tudatosan, a korábbi tapasztalatokat és benyomásokat szubjektíven értékelve, csak korlátozottan racionális döntéseket tudnak hozni, amelyeket nemcsak a gazdasági kalkulációk, hanem gazdaságon kívüli hatások is erőteljesen befolyásolnak. Viszont a háztartások tömeges döntéseinek következtében már kirajzolódnak a hasonló jövedelmű és hasonló preferenciákkal rendelkező családok lakóövezetei, amelyek a lakások nagyságával, az épületek jellegével és a közlekedési viszonyokkal (esetleg faji elöítéletekkel) is kapcsolatba hozhatók.

\section{A monocentrikus városszerkezet és kiterjesztése}

A fentiek alapján a monocentrikus modellben a városi területek iránt egyaránt megnyilvánul a vállalatok és a háztartások kereslete, alapvető: BRC-függvényeik hasonló alakúak és a városközponttól távolodva csökkenő lejtésüek. Egy területet (ingatlant) az bérel, legyen az vállalat, avagy háztartás, aki ezért a területért a legnagyobb bérleti díjat képes megajánlani. Alonso kimutatta, hogy az ismertetett feltételek alapján egyetlen piacpont mint centrum körül megadható egy koncentrikus körgyürükböl, zónákból, övezetekböl álló városszerkezet. Egy-egy körgyürü homogén, azaz hasonló paraméterü gazdasági tevékenységeket végző cégek, vagy hasonló jövedelmü és fogyasztói preferenciákkal bíró háztartások bérelnek területet. Kérdés, hogyan jellemezhető a városi területhasználat a vállalatok és háztartások keresletét együtt vizsgálva?

$\mathrm{Az}$ Alonso-modellként ismert hagyományos monocentrikus városmodellben a BRC-függvényeket vizsgálva általában három zónát különítenek el (5. ábra). Az előző fejezetekben írottakat felhasználva a három zóna (Johnston et al 2000; Lengyel 1994):

- A városközpontban és szük környezetében van az említett $\mathrm{CBD}$, ahol azok az üzleti szolgáltatást, pénzügyi, kiskereskedelmi stb. tevékenységet végző cégek találhatók, amelyek viszonylag kisebb területet igényelnek, nagyon fontos a piac közelsége, az egész város területéröl fogadnak üzleti partnereket és magas bérleti díjat tudnak ajánlani (BRC függvényeik a legmeredekebbek).

- A következő körgyürüben a feldolgozóipari (termelö)vállalatok, nagykereskedelmi cégek, lakossági szolgáltatók vannak (többek között közszolgáltatást nyújtók: iskolák, kórházak stb.) kisebb bérleti díjakkal, akiknek szintén fontos a piac közelsége, a szolgáltatást igénybe vevők elérhetősége.

- A lakóövezet a harmadik zóna, amelyen belül előbb többemeletes házak helyezkednek el (kisebb méretü bérlakásokkal, olcsó tömegközlekedéssel), majd a családi házas részek következnek (napi autóhasználattal). Ettől távolabb már mezőgazdasági hasznosítású földterületek találhatók. 
5. ÁBRA

A hagyományos monocentrikus városmodell

(Traditional Monocentric Urban Model)

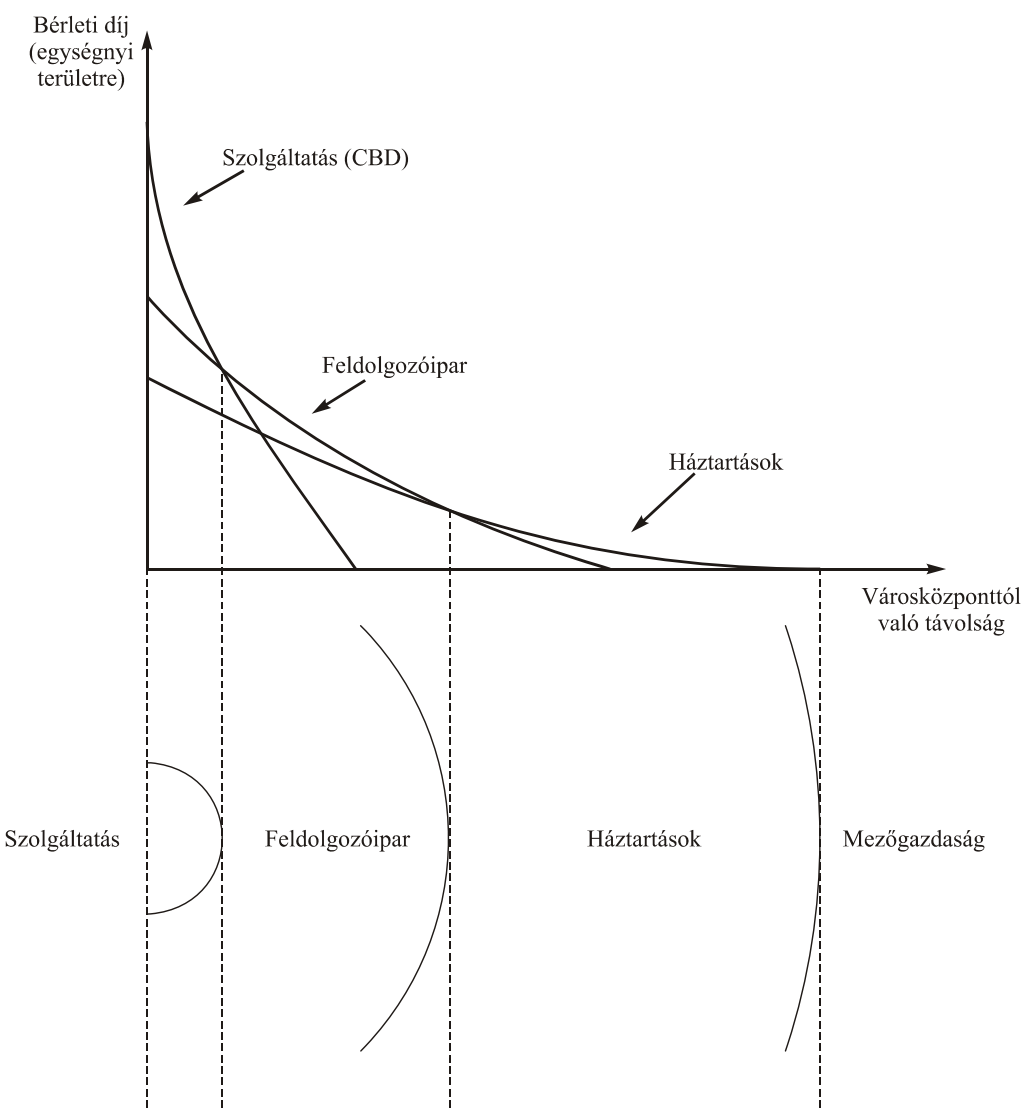

Amint említettük, a zónák nem határolódnak el mereven, hanem csak jelzik, hogy milyen jellegü tevékenység várhatóan hol bérel területet. Mindegyik zóna „,kevert”, pl. a CBD-ben bérelhetnek lakást magas jövedelmü háztartások is (föleg toronyházakban), vagy müködhetnek ott feldolgozóipari vállalatok központi részlegei (vezérigazgatósága) is. Az is megfigyelhető, hogy a többszintes épületek földszintjén és alsóbb emeletein általában irodák, üzletek, míg feljebb lakások találhatók, mivel a lakossági szolgáltatások BRC-függvénye a háztartásokénál alig meredekebb. Ez az elméleti modell csak azt mondja ki: az eltérő gazdasági tevékenységeket végző cégek és a háztartások által megajánlható bérleti díjak különbözőek és a hasonló tevékenységeknél nagy valószínüséggel hasonló BRC-függvények vannak, így a „racionális” városi területhasználatnál a városközpont körül övezetek alakulnak ki, amelyeknél megadható a bérlők domináns „típusa”. 
A hagyományos monocentrikus városmodell felépítése formailag részben hasonló Burgess városökológiai modelljéhez, aki a 20. század elején próbálta Chicago empirikus vizsgálata alapján megadni a városi területhasználat törvényszerüségeit (Cséfalvay 1994; Mészáros 2000; Nemes Nagy 1998). Viszont az Alonso-féle modell mint elméleti közgazdaságtani modell nem adja meg az egyes zónákban folyó konkrét tevékenységeket (amelyek városonként, történelmi koronként eltérhetnek egymástól), hanem csak azt állítja, hogy a BRC-függvények alapján a piaci folyamatok övezeteket alakítanak ki (az övezetek városonként eltérhetnek egymástól). Megjegyezzük, hogy az üzleti szféra és a háztartások mellett nyilván kormányzati és non-profit szervezetek is használják a városi területeket.

Az eddig vizsgált monocentrikus városmodell túlzottan leegyszerüsített feltételekből indul ki, amelyek egy része nem teljesül a valóságban. A feltételek lazításával, a gyakorlatiasabb szempontok figyelembevételével a monocentrikus modell kiterjesztésére több kísérlet történt, a legfontosabb módosítások (Anas-ArnottSmall 1998; McCann 2001):

- Az egyetlen, pontszerü térbeli piac túl erös megszoritás, pl. az exportcégek piacai külföldön vannak, hasonlóan a félkésztermékek gyártóinak piaca is egykét célvállalat, amely nem a városközpontban (sokszor nem is a városban) müködik.

- Mindegyik város gazdasága nyitott, azaz a jövedelmek városon kívüli cégekhez, háztartásokhoz is kerülhetnek, illetve jelentős lehet az ingázás más településekröl.

- A vállalatok általában nem „,egytermékesek”, hanem többféle tevékenységet végeznek, több lábon állnak, amely tevékenységi kör is sokszor módosulhat, továbbá jelentősek a telephelyváltással (avagy lakáscserével) járó költségek, emiatt általában nem a pillanatnyi, hanem a hosszabb távra becsült jövedelmek és bevételek alapján bérelnek épületet (vagy lakást).

- A háztartások felhasználható jövedelmei eltérőek, részben a család nagysága, részben a munkabérek különbözősége miatt. Jelentős lehet a jövedelemtranszfer (pl. szülő-gyerekek között) és a tőkejövedelem is, illetve a családok jövedelmeik egy részét nem fogyasztják el, hanem megtakarítják, többek között ingatlanokban (Lengyel 1993).

- A valóságban a vállalatok és családok alulinformáltak és korlátozottan racionálisak, preferenciáik gyorsan változhatnak, és nincsenek pontosan megfogalmazva, ezért általában elfogadnak egy közelítő megoldást, ott is bérelhetnek területet, ahol számukra kevésbé kedvező.

- A szállitás (közlekedés) nem légvonalban történik, hanem az utakon, utcákon, ezért a közlekedési „,folyosók” figyelembe vétele is lényeges, továbbá kedvező elérhetőségük miatt a mellettük levő területek is felértékelődnek.

- A szállítás, közlekedés (az autóhasználat) fajlagos költsége az utóbbi évtizedekben relatíve csökkent (napjainkban a jövedelem egyre kisebb hányada fordítódik munkába járásra), így nem a földrajzi távolság, hanem inkább az idöbe- 
li megközelithetöség (gyorsforgalmi utak, utcák elérhetösége) vált fontossá, részben emiatt a környező településekröl is sokan bejárnak dolgozni.

- Egyes tevékenységek nem lehetnek bárhol (pl. környezeti problémák miatt a vegyi üzemek, vagy a zaj miatt a repülöterek), illetve nagy területigényük folytán az alacsonyabb bérletủ telkek jöhetnek csak szóba (pl. szállítmányozási cégeknél).

- Agglomerációs elönyök is fellépnek, föleg a lokalizációs elönyök, amelyek ugyanazon iparág/üzletág (városon belüli) cégeinek és a kapcsolódó szolgáltatásoknak a térbeli koncentrációját segítik elő a szinergikus hatások, az információk túlcsordulása stb. révén (Rechnitzer 1998b).

\section{6. ÁBRA}

A monocentrikus városmodell kiterjesztése (The Extension of the Monocentric Urban Model)

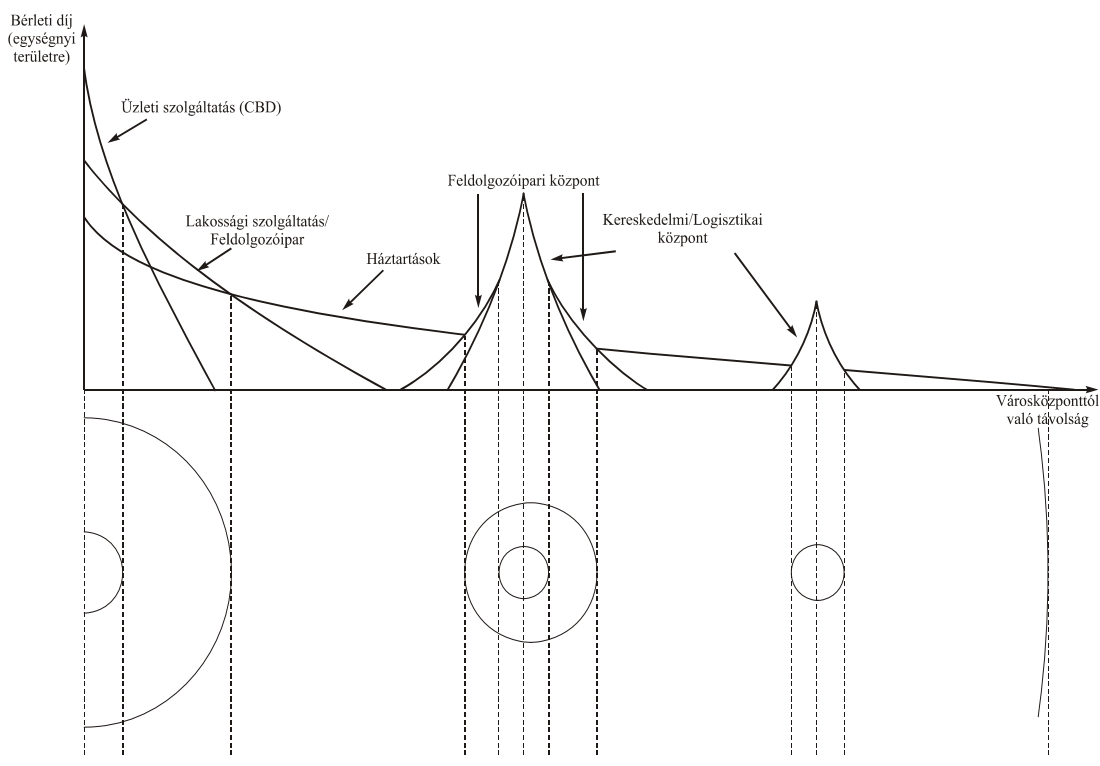

Forrás: Stutz-de Souza $(1998,285)$ és McCann $(2001,120)$ alapján saját szerkesztés.

A fenti szempontok beépítésével a monocentrikus modell kiterjeszthető policentrikus modellé, ahol a városközpont (CBD) mellett további alközpontok is megjelennek (6. ábra). A policentrikus modellben háromféle központot különböztethetünk meg, a központok közötti teret a háztartások lakásai töltik ki, elöbb többszintes házak, majd a CBD-től távolodva sorházak és családi házak találhatók:

- A városközpont (CBD) ekkor is elkülönül, ahol (toronyházakban, emeletes irodaházakban) a legjövedelmezőbb üzleti szolgáltatások mellett a kiemelt kormányzati hivatalok többsége (polgármesteri hivatal stb.) is megtalálható. A CBD-től távolodva többszintes épületek vannak, ahol feldolgozóipari cégek központi részlegei (nem a termelőegységek, hanem pénzügyi, marketing, 
számviteli stb. részlegek) müködnek, valamint lakossági szolgáltatók, illetve az emeleteken lakások is találhatók.

- Megjelennek a feldolgozóipari központok, amelyek a városközponttól távolabb, általában közlekedési csomópontban találhatók (ipari parkok, tudományos parkok stb.). Az (al)központ kialakulását a feldolgozóipar agglomerálódása teszi lehetővé (főleg a termelöüzemeké, pl. egy integrátor cég és beszállítói), amely ipar főleg városon kívüli piacra (exportra) termel, de ott koncentrálódnak a kapcsolódó szolgáltatások (nagykereskedelem, bankfiók stb.) is, amelyek kisebb területigényük miatt az alközpont centrumában levő magasabb bérleti díjú irodaházakban müködnek. A feldolgozóipari cégek üzemeibe a jó közlekedési lehetőségek miatt a környező településekről is bejárnak dolgozni.

- A kereskedelmi/logisztikai központok (bevásárlóközpontok, raktárbázisok, repülőtér stb.) a város széle felé helyezkednek el, kiválóan megközelíthető közlekedési csomópontokban, ahol már olcsóbbak az ingatlanok (amelyek pl. a parkolókhoz szükségesek). Ezek az (al)központok nemcsak a városban müködő, hanem a környező településeken levő cégeket, háztartásokat is kiszolgálják.

A policentrikus modell mint absztrakció már viszonylag jól leírja a területhasználatot, főleg az új, vagy újonnan átépült nagyvárosoknál többé-kevésbé megfigyelhető ez a városszerkezet, pl. Minneapolis-St. Paul, Vancouver, Hong kong, Toronto stb. (Stutz-de Souza 1998). Természetesen ez az elméleti modell csak közgazdasági feltételeket vesz figyelembe, az egyes városoknál a földrajzi környezet (domborzat, folyók, tavak stb.), az évszázadok alatt kialakult városszerkezet (történelmi városrészek, közlekedési szerkezet), a várospolitika és a településrendezési elöírások, a településfejlesztési elképzelések, a településmarketing céljai és eszközei stb. torzíthatják a gazdasági racionalitáson alapuló területhasználatot (Garamhegyi-Révész 2000; Kozma 2002; Mészáros 1994). A városszerkezet, a városok funkciói, illetve a városok versenyképessége is befolyásolják, hogy milyen intézmények és munkahelyek jönnek létre (Lengyel 2000; Lengyel-Rechitzer 2000).

Lényeges, hogy sok helyen, föleg Európában a termőföldet nem engedik felparcellázni, hanem környezetvédelmi szempontokat is figyelembe véve a városok körül fenntartanak zöldövezeteket (greenbelts), mezőgazdasági, vagy természetvédelmi területeket. Nagyon fontos, hogy nemcsak bérelt lakások vannak, hanem olyanok is, amelyeket a tulajdonos használ, ezek a lakások részben ingatlanmegtakarításként funkcionálnak, ahol a hosszú távú várakozások, esetleges spekulációs célok is alapvetőek lehetnek, illetve erős lehet a megszokott környezethez való ragaszkodás, a sznob-hatás, az életmód, a mintakövetés, a lakásépítési szokások stb. (Lengyel 1991; 1993). Kiemelt szerepe lehet az említett extern hatásoknak, amelyek nemcsak a háztartások között léphetnek fel, hanem a termelők és háztartások között is, illetve a közlekedés is okozhat negatív externáliákat (Lengyel-Mozsár 2002).

Az Alonso-féle megközelítés, amely a szokásos közgazdaságtani alapokra helyezi a városi területhasználat vizsgálatát, az 1960-as években alapvető változást hozott a 
városgazdaságtanban. A korábbi, föleg településföldrajzi és városszociológiai alapokon álló felfogások megpróbálták alkalmazni Thünen mezőgazdasági földhasználati modelljét a városi területhasználatra, de a precíz közgazdaságtani alapok hiányosságai, a fogalmak pontatlanságai miatt sokszor keverednek az okok és okozatok (Cséfalvay 1994, 226-229; Kovács 2001, 88-89). A bérleti díj függvény bevezetésével a városi területhasználat összefüggései megalapozottan elemezhetök, visszavezethetők a közismert mikroökonómiai fogalmakra és eszköztárra. A hetvenes évektől megjelent elismert regionális és városgazdaságtani monográfiák mindegyike az Alonso-féle felfogásból indult ki (Arnott 1996; Briassoulis 1999; Fujita 1989; Harvey 1996; McCann 2001; Mills 1987; Mills-Hamilton 1994).

Megjegyezzük, hogy a városközponttól távolodva a területhasználat térbeli intenzitása, valamint a népsürüség is csökken, amit egy negatív kitevőjű exponenciális függvénnyel írhatunk le (Beckmann 1999; Johnston et al 2000):

$$
D(x)=D_{0} e^{-b x}
$$

ahol $x$ a városközponttól (CBD-töl) mért távolság, $D_{0}$ a központ „sürüsége” és $b$ egy pozitív konstans. Ez a konstans egy meredekségi tényező: $b=-D^{\prime} / D$ (az $x$ szerinti $D^{\prime}$ első derivált alapján), amit sürüségi gradiensnek (density gradient) is neveznek. A gradiens a népesség városi koncentrációja összehasonlító vizsgálatára is használatos, pl. összevetve egy adott időpontban különböző városok gradienseit, avagy különböző időpontokban ugyanazon város gradiensét (Anas-Arnott-Small 1998, 1437). Kimutatható, hogy háztartások esetében az (5) képlet jelöléseit alkalmazva: $b \cong t(x) / y$, így az ingázási költség és a jövedelem aránya határozza meg egy-egy városban a gradiens nagyságát (Beckmann 1999, 139). Nyilvánvaló, hogy a $D(x)$ függvény megfelel a BRC-függvények burkológörbéjének.

\section{Összegzés}

A városi terület szűkös erőforrás, ezért a társadalomnak gazdálkodni kell vele, hogy optimálisan tudja hasznosítani. A közgazdaságtudomány gondolat- és fogalomrendszere alapján a városi területhasználat vizsgálatára több modellt dolgoztak ki, amelyek közül a monocentrikus modellnek alapvető a szerepe. Kimutatható, hogy a bérleti díj függvényre támaszkodva a monocentrikus városmodellben a városi területek hasznosítása hatékony (Pareto-optimális), így ez a modell a városi területhasználat térbeli egyensúlyi modellje (Fujita 1989; Straszheim 1987). A modellt sokan vizsgálták és próbálták kiterjeszteni a valós városi problémákat is beépítve, véleményünk szerint a policentrikus modell megfelelő általánosításnak tünik (Anas-Arnott Small 1998; McCann 2001). A közgazdasági eszközökkel jól leírható szempontok mellett fontossá váltak a pénzben nehezen mérhető tényezők, pl. a vállalatok agglomerációs előnyei, illetve a lakókörnyezetböl eredő extern hatások, sokszor szubjektív elvárások is.

A monocentrikus modellben a neoklasszikus közgazdaságtan hagyományos feltételeiből indultunk ki (tökéletes verseny, állandó skálahozadék, általános egyensúly 
stb.). Napjainkban egyre inkább elfogadottá válik és az empirikus vizsgálatok is alátámasztják a Krugman-féle térgazdaságtan megközelítését, amely a monopolisztikus versenyt, a növekvő skálahozadékot, a parciális egyensúlyt, az agglomerációs előnyök kiemelt szerepét veszi alapul (Ács-Varga 2000; Krugman 1995; 2000b). A globális folyamatok, a posztfordista gazdaság, a szolgáltatások szerepének felerősödése stb. egy új gazdasági teret hozott létre, amelyet a régi eszközökkel nem lehet megfelelő módon leírni (Benko 1999; Enyedi 1996, 2000). Ebben az új gazdasági térben a méretgazdaságosság, az innováció és az agglomerációs előnyök meghatározóvá válása miatt a térbeli koncentrációs folyamatok felerösödtek, a nagyvárosok szerepe felértékelődött (Glaeser 2000; Henderson 1996b; Krugman 1996; 2000b). A megújuló szemléletnek és eszköztárnak fontos kiindulópontja mind a Thünen-féle termőföld használati, mind az Alonso-féle városi területhasználati modell, amelyek továbbfejlesztése, „megszüntetve-megőrzése” a városgazdaságtan egyik kurrens kutatási területe (Fujita-Thisse 2002; Fujita-Krugman-Venables 1999; McCann 2001).

\section{Irodalom}

Ács, Z.-Varga A. (2000) Térbeliség, endogén növekedés és innováció. - Tér és Társadalom, 4., 23-39. o. Alonso, (1964) Location and Land Use. Harvard University Press, Cambridge.

Anas, A. (1996) Modeling in Urban and Regional Economics. - Arnott, R. (ed) Regional and Urban Economics. Harwood, Amsterdam, 921-1050. o.

Anas, A.-Arnott, R. - Small, K.A. (1998) Urban Spatial Structure. - Journal of Economic Literature, 1426-1464. o.

Arnott, R. (ed) (1996) Regional and Urban Economics. Harwood, Amsterdam,

Barta Gy. (szerk.) (1998) Budapest - nemzetközi város. MTA, Budapest.

Bartke I.-Illés I. (1997) Telephelyelméletek. ELTE Eötvös Kiadó, Budapest.

Beckmann, M.J. (1999) Lectures on Location Theory. Sringer-Verlag, Berlin.

Beluszky P. (2000) A magyarországi településrendszer fejlődése. - Enyedi Gy. (szerk) Magyarország településkörnyezete. MTA, Budapest, 9-76. o.

Beluszky P.-Szirmai V. (2000) A települések társadalma. - Enyedi Gy. (szerk) Magyarország településkörnyezete. MTA, Budapest, 76-98. o.

Benko, G. (1999) Regionális tudomány. Dialóg Campus, Budapest-Pécs.

Berényi I. (1997) A szociálgeográfia értelmezése. ELTE Eötvös Kiadó, Budapest.

Briassoulis, H. (1999) Analysis of Land Use Change: Theoretical and Modeling Approaches. West Virginia University, Morgentown (www.rri.wvu.edu/WebBook/)

Cséfalvay Z. (1994) A modern társadalomföldrajz kézikönyve. IKVA, Budapest.

Enyedi Gy. (1988) A városnövekedés szakaszai. Akadémiai Kiadó, Budapest.

Enyedi Gy. (1996) Regionális folyamatok Magyarországon az átmenet időszakában. Hilscher Rezső Szociálpolitikai Egyesület, Ember-település-régió sorozat, Budapest.

Enyedi Gy. (2000) Globalizáció és a magyar területi fejlődés. - Tér és Társadalom, 1. 1-10. o.

Fujita, M. (1989) Urban Economic Theory. Land use and city size. Cambridge University Press, Cambridge.

Fujita, M. (1996) Urban Land Use Theory. Regional and Urban Economics. - Arnott, R. (ed), Harwood, Amsterdam, 111-188. o.

Fujita, M.-Krugman, P. - Venables, A.J. (1999) The Spatial Economy. Cities, Regions, and International Trade. MIT Press, Cambridge (MA).

Fujita, M.-Thisse, J-F. (2002) Economics of Agglomeration. Cities, Industrial Location, and Regional Growth. Cambridge University Press, Cambridge.

Garamhegyi Á.-Révész B. (2000) A területi marketing, mint az önkormányzatok versenyképességének egy lehetséges eszköze. - Farkas B. - Lengyel I. (szerk.)Versenyképesség - regionális versenyképesség. SZTE GTK Tudományos Közleményei, Szeged, 124-137. o.

Glaeser, E.L. (2000) The New Economics of Urban and Regional Growth. - Clark, G. L.- Feldman, M. P.- Gertler, M. S. (eds) The Oxford 120 
Handbook of Economic Geography, Oxford University Press, Oxford, 83-98. o.

Harvey, J. (1996) Urban Land Economies. (fourth ed.) MacMillan, London.

Henderson, J.V. (1996a) Systems of Cities and Inter-City Trade. - Arnott, R. (ed) Regional and Urban Economics. Part I. Harwood, Amsterdam, 509-557. o.

Henderson, J.V. (1996b) Ways to Think about Urban Concentration: Neoclassical Urban Systems versus the New Economic Geography. - International Regional Science Review, 1\&2, 31-36.o.

Hoover, E.M.-Giarratani, F. (1999) An Introduction to Regional Economics. West Virginia University Morgentown (www.rri.wvu.edu/WebBook/).

Johnston, R.J.-Gregory,D. - Pratt,G. - Watts, M. (eds) (2000) The Dictionary of Human Geography. (fourth ed). Blackwell, Oxford.

Kanemoto, Y. (1996) Externalities in Space. - Arnott, R. (ed) Regional and Urban Economics. Part I. Harwood, Amsterdam, 189-249. o.

Kovács Z. (2001) A települések fejlődése. - Beluszky P. - Kovács Z. - Olessák D. (szerk.) A terület- és településfejlesztés kézikönyve. CEBA, Budapest.

Kozma G. (2002) Terület- és településmarketing. Kossuth Egyetemi Kiadó, Debrecen.

Krugman, P. (1995) Development, Geography, and Economic Theory. MIT Press, Cambridge (MA)

Krugman, P. (1996) Urban Concentration: The Role of Increasing Returns and Transport Cost. - International Regional Science Review, 1\&2, 5-30. o.

Krugman, P. (2000a) A földrajz szerepe a fejlödésben. - Tér és Társadalom, 4. 1-21. o.

Krugman, P. (2000b) Where in the World is the 'New Economic Geography'? - Clark, G.L. - Feldman, M.P. - Gertler, M.S. (eds) The Oxford Handbook of Economic Geography. Oxford University Press, 49-60. o.

Lados M. (1994) A városnövekedés szakaszai - urbanizációs ciklusok. - Rechnitzer J. (szerk.) Fejezetek a regionális gazdaságtan tanulmányozásához. MTA RKK, Győr-Pécs, 186-210. o.

Lengyel I. (1991) A házépítések (anti)szociális támogatásának krónikája. - Tér és Társadalom, 1. 1-22. o.

Lengyel I. (1993) A lakossági megtakarítások területi egyenlőtlenségei a közgazdasági elméletek tükrében. Enyedi Gy. (szerk.) Társadalmi-területi egyenlötlenségek Magyarországon. Közgazdasági és Jogi Könyvkiadó, Budapest, 333-358. o.

Lengyel I. (1994) A telephelyválasztás. - Rechnitzer J. (szerk.) Fejezetek a regionális gazdaságtan tanulmányozásához. MTA RKK, Győr-Pécs, 35-68. o.

Lengyel I. (1999) Mérni a mérhetetlent? A megyei jogú városok vizsgálata többdimenziós skálázással. Tér és Társadalom, 1-2. sz. 53-74. o.

Lengyel I. (2000) A regionális versenyképességröl. - Közgazdasági Szemle, 12. 962-987. o.

Lengyel I-Mozsár F. (2002) A külső gazdasági hatások (externáliák) térbelisége. - Tér és Társadalom. 2. 1-20.o.

Lengyel I.-Rechnitzer J. (2000) A városok versenyképessége. - Horváth Gy. - Rechnitzer J. (szerk.) Magyarország területi szerkezete és folyamatai az ezredfordulón. MTA RKK, Pécs, 130-152. o.

McCann, P. (2001) Urban and Regional Economics. Oxford University Press, Oxford.

McDonald, J.F. (1997) Fundamentals of Urban Economics. Prentice Hall, Upper Saddle River.

Mészáros R. (1994) A település térbelisége. JATEPress, Szeged.

Mészáros R. (2000) A társadalomföldrajz gondolatvilága. SZTE Gazdaság- és Társadalomföldrajzi Tanszéke, Szeged.

Mills, E.S. (ed) (1987) Handbook of Regional and Urban Economics (volume 2). North-Holland, Amsterdam.

Mills, E.S.-Hamilton, B.W. (1994) Urban Economics. (fifth ed) Harper Collins, New York.

Mozsár F. (2000) Az externáliák szerepe a regionális gazdasági teljesítmény magyarázatában és növelésében. - Farkas B. - Lengyel I. (szerk.) Versenyképesség - regionális versenyképesség. SZTE Gazdaságtudományi Kar Közleményei, JATEPress, Szeged, 100-114. o.

Muth, R.F. (1996) Theoretical Issues in Housing Market Research. - Arnott, R. (ed) Regional and Urban Economics. Harwood, Amsterdam, 731-779. o.

Nemes Nagy J. (1998) A tér a társadalomkutatásban. Hilscher Rezső Szociálpolitikai Egyesület, Embertelepülés-régió sorozat, Budapest.

Nijkamp, P. (ed) (1987) Handbook of Regional and Urban Economics (volume1). North-Holland, Amsterdam.

Pearce, D.W. (szerk.) (1993) A modern közgazdaságtan ismerettára. Közgazdasági és Jogi Könyvkiadó, Budapest.

Porter, M.J. (1998) On Competition. Free Press, New York

Rechnitzer, J. (1993) Szétszakadás vagy felzárkózás. A térszerkezetet alakitó innovációk. MTA RKK, Győr-Pécs.

Rechnitzer, J. (1998a) A privatizáció regionális összefüggései. ÁPV Rt., Budapest. 
Rechnitzer, J. (1998b) Területi stratégiák. Dialóg Campus, Budapest-Pécs.

Samuelson, P.A. (1983) Thünen at Two Hundred. - Journal of Economic Literature, 12. 1468-1488. o.

Solow, R.M (1973a) On Equilibrium Models of Urban Location. - Parkin, M.-Nobay, A.R. (eds) Essays in Modern Economics. Longmans, London, 3-16. o.

Solow, R.M (1973b) Congestion Cost and the Use of Land for Streets. - Bell Journal of Economics and Management Science. 4. 602-618. o.

Straszheim, M. (1987) Theory of Urban Residential Location. - Mills, E. S. (ed) Handbook of Regional and Urban Economics (volume 2). North-Holland, Amsterdam, 717-757. o.

Stutz, F.P.-De Souza, A.R. (1998) The World Economy. Resources, Location, Trade, and Development. Prentice Hall, Upper Saddle River.

Timár J.-Váradi M. (2000) A szuburbanizáció egyenlötlen területi fejlődése az 1990-es évek Magyarországán. - Horváth Gy. - Rechnitzer J. (szerk.) Magyarország területi szerkezete és folyamatai az ezredfordulón. MTA RKK, Pécs, 153-175. o.

Varga A. (2002) Thünen és az „Új Gazdaságföldrajz” térgazdaságtana. Kézirat, PTE KTK Gazdaságelméleti Tanszék, 14. o.

Varian, H.R. (2001) Mikroökonómia középfokon. Közgazdasági és Jogi Könyvkiadó, Budapest.

\section{ON THE MONOCENTRIC MODEL OF URBAN LAND USE}

\section{IMRE LENGYEL - FERENC MOZSÁR}

In towns, land use and in settlement structure connected with it as well as the supply and demand characteristics of properties can be analysed with different methodologies and models. In urban economics mococentric urban model is a well-known concept, which was elaborated by Alonso in 1964 with the further development of Thünen's theory concerning to agricultural land use. Alonso applied the main ideas, concepts and methodologies of neo-classical economics for his urban structure analysis with the introduction of the rent function and attempted to present the features of spatial balance between supply and demand of urban land.

In our study, after the introduction of the most important concepts we present the main ideas of the monocentric urban model. We derive in detail the expressions giving information on the intensity of land use, and which can characterise the enterprises' rent functions. We also analyse home selection decisions of households. Based on the offering rent function of the two types of microeconomic organisation (the enterprises and the households) we present the monocentric model and its polycentric extension seemed to be applicable nowadays. In the study we review and interpret the international literature's widely accepted recent theoretical results. 